\title{
PENYAKIT CHARCOT MARIE TOOTH ONSET LANJUT
}

\author{
LATE ONSET CHARCOT MARIE TOOTH DISEASE \\ Kenny Merryn, * Jimmi Sabirin, * Octaviani*
}

\section{ABSTRACT}

Charcot Marie Tooth's disease (CMT) is a hereditary sensoric motoric polineuropathy. Late onset CMT are rare reported in Indonesia. A woman 48 years old has numbness in her both arm and leg gradually since 5 years ago, followed by deformities and weakness. Her cousin has the same disease. In physical examination, there were flaccid type tetraparesis, socks and gloves hypesthesia, steppage gait, pes cavus, hammer toes, thenar, hypothenar, and extensor hallucis longus muscle atrophy bilaterally. Electrophysiology studies showed mixed sensoric and motoric polineuropathy with symetrically demyelinating and uniform slowing. Management were ascorbic acid, neurotrophic, physiotherapy, and occupational therapy.

Keywords: Charcot Marie Tooth, hammer toes, pes cavus, steppage gait

\begin{abstract}
ABSTRAK
Penyakit Charcot Marie Tooth (CMT) merupakan polineuropati motorik dan sensorik herediter. Kasus CMT onset lanjut di Indonesia masih sangat jarang dilaporkan. Seorang wanita 48 tahun mengalami kesemutan pada kedua lengan dan tungkai sejak 5 tahun secara perlahan diikuti perubahan bentuk tangan dan kaki serta kelemahan. Riwayat sepupu mengalami keluhan serupa. Pemeriksaan fisik didapatkan kelemahan kedua lengan dan tungkai tipe flaksid, hipestesi pola sarung tangan dan kaos kaki, steppage gait, pes cavus, hammer toes, atrofi otot tenar, hipotenar, dan ekstensor halusis longus bilateral. Pemeriksaan elektrofisiologi didapatkan polineuropati motorik sensorik dengan demielinisasi simetris dan perlambatan kecepatan konduksi seragam. Tata laksana pasien ini menggunakan asam askorbat, neurotropik, fisioterapi, dan terapi okupasi.
\end{abstract}

Kata kunci: Charcot Marie Tooth, hammer toes, pes cavus, steppage gait

*Departemen Ilmu Penyakit Saraf FK Universitas Sriwijaya/RSUP Dr. Moh. Hoesin, Palembang. Korespondensi: k3nnym3rryn@ gmail.com.

\section{PENDAHULUAN}

Penyakit CharcotMarie Tooth(CMT) merupakan penyakit polineuropati motorik dan sensorik herediter. CMT dibedakan menjadi dua tipe yaitu tipe demielinisasi dan aksonal. Gambaran klinis CMT adalah kombinasi defisit motorik lower motor neuron (LMN) dan tanda atau gejala sensoris (neuropati motorik-sensorik). Pendekatan klinis dengan anamnesis, pemeriksaan fisik, dan pemeriksaan elektrodiagnosis dapat membantu menegakkan diagnosis. Pemeriksaan genetik merupakan baku emas dalam diagnosis neuropati herediter.

\section{KASUS}

Seorang wanita usia 48 tahun mengalami kesemutan pada kedua lengan dan tungkai sejak 5 tahun secara perlahan dan diikuti perubahan bentuk tangan dan kaki. Sejak 2 minggu lalu, kesemutan makin memberat diikuti dengan kelemahan dan kesulitan melakukan aktivitas kecil seperti mengancingkan pakaian. Pasien juga mengalami nyeri pada kaki yang hilang timbul terutama saat aktivitas tanpa disertai nyeri pinggang, gangguan buang air besar, dan buang air kecil. Pasien tidak memiliki riwayat kencing manis, konsumsi alkohol, obat-obatan lainnya, tumor atau benjolan, maupun trauma. Saudara sepupu pasien memiliki keluhan serupa. Riwayat perkembangan saat kanak-kanak tidak ada kelainan.

Pada pemeriksaan fisik didapatkan kelemahan kedua lengan dan tungkai dengan kekuatan 4, penurunan tonus otot dan refleks tendon dalam pada keempat ekstremitas, hipestesi pola sarung tangan dan kaos kaki, steppage gait, atrofi otot tenar, otot hipotenar bilateral, otot ekstensor halusis longus, dan terdapat pes cavus serta hammer toes (Gambar 1).

Pada pemeriksaan laboratorium darah lengkap, kimia darah, dan elektrolit dalam batas normal. Pada pemeriksaan elektrofisiologi didapatkan polineuropati motorik sensorik dengan demielinisasi simetris dan perlambatan kecepatan konduksi seragam.

Berdasarkan anamnesis dan pemeriksaan yang dilakukan, pasien ini dapat didiagnosis sebagai polineuropati perifer herediter (CMT). Tata laksana 


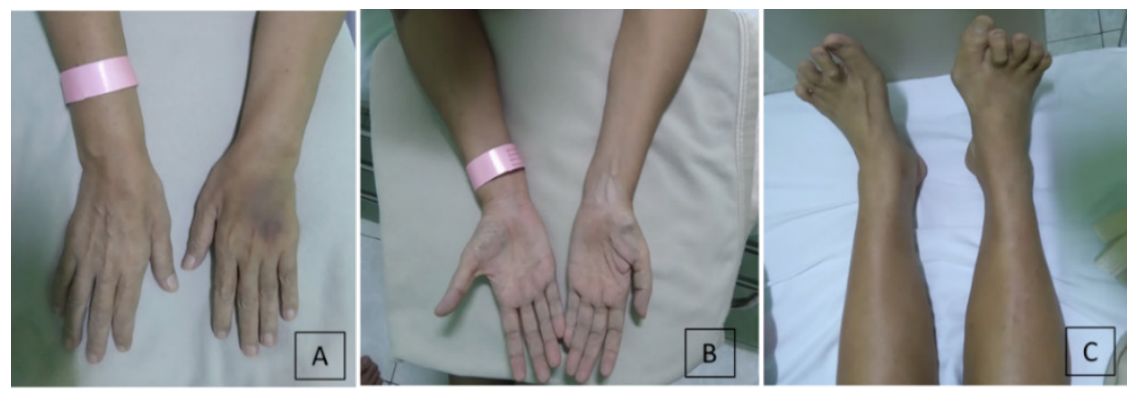

Gambar 1. Pemeriksaan Fisik Lengan dan Tungkai

(A) dan (B) atrofi otot tenar, otot hipotenar bilateral. (C) atrofi otot ekstensor halusis longus, pes cavus, dan hammer toes.

yang diberikan pada pasien ini yaitu asam askorbat, amitriptilin, neurotropik, fisioterapi, dan terapi okupasional.

\section{PEMBAHASAN}

CMT merupakan suatu neuropati motorik dan sensorik herediter. Beberapa jenis neuropati herediter lainnya yaitu neuropati motorik distal herediter yang melibatkan motorik dan neuropati sensorik/otonom herediter yang melibatkan saraf sensorik dan otonom. Ketiga jenis neuropati ini sering disebutkan sebagai CMT dan penyakit terkait. ${ }^{2}$

Prevalensi CMT sekitar 1 kasus pada 2500 orang pada distribusi global dan tidak terkait predisposisi etnik. Prevalensi CMT di Amerika Serikat diketahui sekitar 125.000 kasus. ${ }^{2,4}$ CMT1A berhubungan dengan duplikasi 17 p11.2 pada bagian yang memiliki protein mielin perifer gen 22 dan merupakan CMT tipe demielinisasi yang paling banyak ditemukan, dan berkisar $50 \%$ dari semua tipe CMT. Mutasi pada gen gap junction beta 1 (GJB1) menyebabkan CMTX sekitar 10\%- 20\% kasus CMT. CMT1B berhubungan dengan mutasi gen myelin protein zero (MPZ) dengan angka kejadian kurang dari $5 \%{ }^{2,4}$

Pola pewarisan autosomal dominan merupakan pola pewarisan utama pada CMT dengan transmisi vertikal dari generasi ke generasi. Pola pewarisan secara autosomal resesif kemungkinan besar dapat terjadi. Selain itu juga terdapat pola pewarisan terkait kromosom X (bila tidak terdapat transmisi laki-laki ke laki-laki). Namun, pada beberapa kasus dengan riwayat keluarga yang tidak jelas, kasus ini bisa dipertimbangkan sebagai kasus sporadik yang dikarenakan mutasi de novo, berkurangnya penetrasi/variabilitas intrafamilial, dan suatu pewarisan autosomal resesif. Jadi, tidak adanya riwayat keluarga dengan neuropati tidak menghalangi klinisi untuk mempertimbangkannya sebagai kasus genetik (Tabel 1)..$^{2,5-6}$

Gambaran utama pada CMT adalah kombinasi defisit motorik LMN dan tanda atau gejala sensoris (neuropati motorik-sensorik). ${ }^{2-3,7}$ Pada CMT klasik memiliki tahap perkembangan awal normal, misalnya penderita bisa berjalan pada tahun pertama kehidupan. Kemudian akan diikuti dengan kelemahan bertahap yang progresif dan hilangnya fungsi sensoris pada dua dekade pertama kehidupan. Tanda klasik pada CMT yaitu steppage gait, pes cavus, distribusi gangguan sensoris pola sarung tangan dan kaos kaki, dan atrofi pada tangan. Walaupun biasanya saraf sensoris dan motorik terkena, karakteristik dominan pada kebanyakan kasus lebih terkait pada gangguan motorik. . $^{1-2,7-8}$

Pada pemeriksaan fisik dapat ditemukan berkurangnya atau hilangnya refleks tendon dalam yang difus dan bersifat simetris. Gerakan halus pada tangan penderita CMT seperti menggunakan kunci pintu, mengaitkan kancing, dan lainnya juga terganggu. Otot-otot dalam dan superfisial yang diinervasi oleh saraf peroneal, seperti otot tibialis anterior, peroneus brevis, dan peroneus longus lebih menunjukkan gejalanya dibandingkan pada otot plantar fleksi yang dipersarafi saraf tibialis, seperti gastrocnemius. Onset munculnya manifestasi klinis berbeda-beda tergantung dengan subtipe genotip, yaitu onset dini, bentuk infantil dengan gangguan tahapan perkembangan (Dejerine Sottas Neuropathy), dan onset lambat (dewasa). Gejala biasanya progresif lambat terutama pada bentuk klasik dan fenotip onset 
Tabel 1. Klasifikasi CMT ${ }^{2-3}$

\begin{tabular}{|c|c|}
\hline Tipe & Gen/ Lokus \\
\hline \multicolumn{2}{|c|}{ Autosomal Dominan CMT1 (ADCMT1) } \\
\hline CMT1A & Dup 17p (PMP22) \\
\hline CMT1B & MPZ \\
\hline CMT1C & SIMPLE \\
\hline CMT1D & EGR2 \\
\hline CMT1E & Mutasi titik PMP22 \\
\hline CMT1F & NEFL \\
\hline \multicolumn{2}{|c|}{ Neuropati Herediter dengan Kecenderungan Kelumpuhan Tekanan } \\
\hline HNPP & Del $17 \mathrm{p} /$ mutasi titik PMP22 \\
\hline \multicolumn{2}{|l|}{ CMT Terkait Kromosom-X } \\
\hline CMTX1 & GJB1 \\
\hline \multicolumn{2}{|c|}{ Autosomal Dominan CMY2 (ADCMT2) } \\
\hline CMT2A & MFN2 \\
\hline СMT2B & RAB7 \\
\hline СMT2C & TRPV4 \\
\hline CMT2D & GARS \\
\hline CMT2E & NEFL \\
\hline CMT2F & HSP77 (HSPB1) \\
\hline CMT2L & HSP22 (HSPB8) \\
\hline CMT1K & GDAP1 \\
\hline \multicolumn{2}{|c|}{ Autosomal Resesif CMT Demielinisasi (CMT4) } \\
\hline CMT4A & GDAP1 \\
\hline СMT4B1 & MTMR2 \\
\hline СMT4C & SH3TC2 \\
\hline CMT4F & PRX \\
\hline CMT4J & FIG4 \\
\hline
\end{tabular}

Autosomal Resesif CMT Aksonal (AR-CMT2)

AR-CMT2A

LMNA

AD: autosomal dominan; AR: autosomal resesif, Dup: duplikasi; MPZ: myelin protein zero; SIMPLE: small integral membrane protein of the lysosome/late endosome; EGR2: early growth response 2; PMP 22: peripheral membrane protein 22; NEFL: neurofilament light chain: HNPP; hereditary neuropathy with liability to pressure palsies; Del: delesi; GJB1: gap junction protein beta 1; MFN2: mitofusin 2; RAB7: anggota onkogen RAS; GARS: glycyl rTNA syntethase; HSP27: heat shock 27 kDa protein 1; HSP 22: heat shock 22 kDa protein 8: GDAP1: ganglioside induced differentiation associated protein 1; MTMR2: myotubularin related protein 2; SH3TC2: dimain SH3 dan pengulangan tetratricopeptide 2; PRX: periaksin; FIG4: homolog FIG4; LMNA: lamin A/C.

lambat, namun bila muncul gejala berat umumnya pada bentuk onset dini. ${ }^{2,8}$

Tahapan pertama yang perlu dilakukan adalah mengetahui apakah penderita mengalami suatu neuropati genetik atau bukan. Jika terdapat riwayat salah satu orang tua dengan penyakit tersebut kemungkinan pola pewarisannya secara autosomal dominan atau terkait kromosom X. Jika terdapat beberapa saudara (sepupu) dengan penyakit tersebut, maka pola pewarisan kemungkinan secara autosomal resesif. Namun, untuk mengetahui CMT akan lebih sulit jika tidak ada riwayat keluarga atau merupakan keluarga kecil. Faktor yang memungkinkan hal tersebut merupakan suatu neuropati herediter yaitu, muncul saat masih anak-anak, progresif lambat, adanya deformitas pada kaki, dan adanya gejala sensoris. ${ }^{1-3}$

Pemeriksaan genetik merupakan baku emas dalam diagnosis neuropati herediter. Namun, pemeriksaan perlu dilakukan dengan memperhatikan alasan biaya karena begitu banyak gen yang diketahui 
berkaitan dengan CMT.-3 Pemeriksaan genetik seringkali tidak memberikan kesimpulan penyebab CMT karena banyak gen yang menyebabkan CMT dan tidak semua gen penyebab CMT bisa teridentifikasi. ${ }^{9}$ Oleh karena itu perlu menerapkan strategi sebelum melakukan pemeriksaan genetik. Hal yang perlu dipertimbangkan pada strategi pemeriksaan genetik yaitu jumlah subtipe kasus, fenotip yang tampak pada pasien, karakteristik elektrofisiologi, dan pola pewarisan. Namun hal ini juga menjadi sesuatu yang menarik karena gen yang sama dapat memberikan gambaran demielinisasi, aksonal, atau bentuk intermediate dan bisa juga memberikan gambaran autosomal dominan atau resesif sesuai perjalanannya sendiri dan posisi mutasi. Beberapa elemen yang dapat mengarahkan klinisi sebelum melakukan pemeriksaan genetik yaitu usia onset, tanda dan gejala, pola neurofisiologi, pola pewarisan, dan etnik.-3

Penderita dengan fenotip klasik yang perkembangan kemampuan berjalannya normal dan muncul kelemahan atau hilangnya sensoris selama dua dekade pertama kehidupan, dimasukkan ke dalam kelompok pertama. Gangguan memberat secara perlahan dan penderita jarang membutuhkan alat bantu seperti ortosis pergelangan kaki. Kebanyakan kategori pasien ini mengalami CMT1A dan CMTX pada laki-laki. ${ }^{1-2,8}$ Kelompok kedua yaitu dengan fenotip onset dini, dengan gejala penderita tidak bisa berjalan sejak usia sekitar 15 bulan. Penderita ini seringkali memiliki gejala yang lebih berat dan membutuhkan alat bantu seperti ortosis, kursi roda, dan tongkat. Spektrum genetik CMT onset dini ini sangat heterogen, bisa berupa bentuk dominan atau resesif. Kebanyakan kondisi seperti ini fenotip dari demielinisasi dengan kecepatan hantar saraf (KHS) motorik yang sangat lambat dan paling sering oleh CMT1A, CMT1B, dan CMT1E untuk bentuk dominan dan CMT4A, CMT4C, dan CMT4F untuk bentuk resesif. Selain ini pada fenotip demielinisasi, neuropati aksonal onset dini yang berat bisa disebabkan mutasi MFN2 (CMT2A) atau GDAP1 (AR-CMT2K). Penderita dengan CMT2A seringkali mengenai pada bayi dan kanak-kanak dengan predominan pada neuropati motorik. ${ }^{1-2,8}$ Kelompok fenotip ketiga yaitu onset dewasa, penderita tidak menunjukkan gejala CMT hingga dewasa, sering kali tidak sampai usia 40 tahun. Kelompok penderita ini dengan CMT aksonal atau penderita dengan CMT1B onset lanjut. ${ }^{1-2,8}$

Pengenalan tanda dan gejala tambahan dapat membantu dalam mendefinisikan tipe CMT. Split hand syndrome (otot abduktor pollicis brevis menjadi lebih atrofi dan lebih lemah dibandingkan otot interosseus dorsal pertama) menjadi suatu tanda pembeda CMTX, terutama pada laki-laki. Disfungsi sistem saraf pusat ringan atau episode seperti stroke berupa disartria, kelemahan episodik, dan ataksia pernah ditemukan CMTX. Atrofi optik dan tanda piramidal bisa ditemukan pada mutasi MFN2. Paralisis plika vokalis sering ditemukan pada CMT2C yang disebabkan oleh mutasi TRPV4 dan adanya pupil tonik bisa menjadi gambaran klinis tambahan pada onset lambat aksonal karena mutasi MPZ. Amputasi dan ulkus di kulit merupakan gambaran khas CMT2B dan gejala otonom lainnya (misalnya hiper/hipohidrosis). Mutasi pada SH3TC2 pada CMT4C sering memberikan gambaran skoliosis berat. $^{1-2}$

Pemeriksaan elektrofisiologi dapat membantu dalam menentukan jenis CMT bentuk demielinisasi (CMT1) atau aksonal (CMT2). Titik potong standar KHS motorik demielinisasi yaitu $38 \mathrm{~m} /$ detik pada ekstremitas atas. Amplitudo CMAP (compound muscle action potential) dapat berkurang karena hilangnya aksonal sekunder. Pada CMT1A, KHS motorik pada semua saraf mengalami perlambatan yang seragam dengan rentang $17-21 \mathrm{~m} /$ detik. KHS motorik yang sangat lambat $(<10 \mathrm{~m} /$ detik $)$ dapat menunjukkan CMT1B onset dini, mutasi titik PMP22, atau CMT4. Tipe aksonal (CMT2) menunjukkan KHS lebih dari $45 \mathrm{~m} /$ detik namun dengan penurunan compound muscle action potential (CMAP). Pada bentuk dominan intermediate (I-CMT) menunjukkan KHS motorik antara 25 dan $45 \mathrm{~m} /$ detik. Kecepatan konduksi dilakukan pada ekstremitas atas karena amplitudo CMAP pada tungkai sering kali tidak bisa ditentukan, bahkan pada bentuk CMT demielinisasi, karena kegagalan konduksi atau degenerasi aksonal sekunder. ${ }^{2}$ Temuan elektrodiagnostik pada neuropati demielinisasi herediter menunjukkan penyebaran 
yang seragam dengan perlambatan kecepatan konduksi (uniform slowing). Hal ini berbeda dengan perlambatan segmental multifokal pada tipe neuropati lainnya yang berupa dispersi temporal dan hambatan konduksi. Namun, terdapat pengecualian pada wanita dengan CMTX dan beberapa kasus CMT1B dengan mutasi MPZ. Pada kasus tersebut, demielinisasi fokal dengan dispersi temporal dan hambatan konduksi dapat ditemukan. ${ }^{2}$

Pola pewarisan autosomal dominan merupakan pola pewarisan utama pada CMT dengan transmisi vertikal dari generasi ke generasi. Pola pewarisan secara autosomal resesif kemungkinan besar terjadi. Selain itu juga terdapat pola pewarisan terkait kromosom X. Pada beberapa kasus dengan riwayat keluarga yang tidak jelas sehingga kasus seperti ini bisa dipertimbangkan sebagai kasus sporadik. ${ }^{1-2}$

Frekuensi mutasi spesifik dapat mengenai populasi tertentu karena terdapat beberapa laporan CMT pada kelompok etnik tertentu. Di Eropa Utara dan Amerika Serikat, pola autosomal dominan lebih banyak dibandingkan autosomal resesif. ${ }^{2}$

Selain pemeriksaan genetik, dapat juga dilakukan pemeriksaan biopsi saraf dan pemeriksaan histologi. Pemeriksaan biopsi saraf jarang dilakukan untuk menegakkan diagnosis CMT, terutama apabila telah terdapat pemeriksaan genetik. Pada CMT1, saraf perifer memiliki sedikit serabut yang bermielin dan saraf intramuskuler dikelilingi oleh jaringan ikat dan neurilema hiperplastik. Panjang mielin mengalami atrofi di sepanjang serabut. Hipertrofi konsentrik pada selubung lamelar dapat terlihat. Pembentukan seperti umbi bawang (onion bulb) sering ditemukan dan berbentuk sirkumferensial pada sel Schwann dan prosessusnya. Pada CMT2, hilangnya akson dengan degenerasi Wallerian sering ditemui. Pada CMT 3 atau Dejerine Sottas Neuropathy, demielinisasi dengan selubung mielin yang tipis dapat terlihat. ${ }^{1-2,7}$

Pada kasus ini, seorang wanita, 48 tahun dengan kelemahan kedua lengan dan tungkai, penurunan refleks tendon, hipestesi pola sarung tangan dan kaos kaki, gangguan gait (steppage gait), atrofi pada otot intrinsik tangan dan kaki, dan abnormalitas bentuk kaki yaitu pes cavus dan hammer toes. Berdasarkan pemeriksaan neurologis tersebut, kemungkinan lesi pada LMN dengan defisit pada motorik dan sensorik. Terdapat riwayat keluhan serupa pada saudara sepupu (dari pihak ibu), sehingga dapat dipertimbangkan bahwa pasien ini kemungkinan mengalami suatu penyakit herediter yang muncul pada onset dewasa, karena tidak ada gangguan perkembangan saat kanak-kanak.

Pes cavus merupakan salah satu tanda suatu kelainan neurologis pada medula spinalis (ataksia spinoserebelar) dan polineuropati perifer herediter. Pes cavus sendiri terjadi karena ketidakseimbangan antara otot intrinsik kaki dan otot tungkai. Apabila pes cavus terjadi secara bilateral, adanya riwayat keluarga dengan keluhan serupa, terdapat gangguan gait, dan adanya tanda dan gejala neurologis lain, kemungkinan paling besar pasien ini mengalami polineuropati herediter (Gambar 2) ${ }^{2,10}$

Hammer toes merupakan deformitas kaki yang sering ditemui. Hammer toes simpleks berupa deformitas fleksi pada sendi interfalangeal proksimal disertai falang medial dalam posisi relatif plantarfleksi terhadap falang proksimal. Hammer toes kompleks berupa deformitas fleksi pada sendi interfalangeal proksimal disertai ekstensi pada sendi metatarsofalangeal. Hammer toes dapat disebabkan oleh artritis, diabetes melitus, polineuropati perifer, kelainan pada diskus lumbosakral, kelainan neuromuskular, dan kelainan postural. ${ }^{11-12}$ Berbagai etiologi tersebut dapat menyebabkan ketidakseimbangan otot antara otot ekstensor ibu jari kaki dan otot intrinsik fleksor ibu jari kaki. Kekuatan ekstensi dari otot ekstensor digitorum longus dan ekstensor digitorum brevis pada sendi metatarsofalangeal diseimbangkan oleh otot fleksor digitorum longus, interosseus, dan lumbrikal (otot intrinsik). Bila otot-otot intrinsik kaki melemah, maka aksi dari otot ekstensor tidak dapat dilawan sehingga menimbulkan deformitas hammer toes. ${ }^{13}$

Berdasarkan pemeriksaan penunjang laboratorium pasien ini menunjukkan hasil yang normal sehingga menyingkirkan suatu kelainan polineuropati yang disebabkan oleh kondisi metabolik. Untuk menegakkan pasti diagnosis spesifik dan mengarahkan pada 


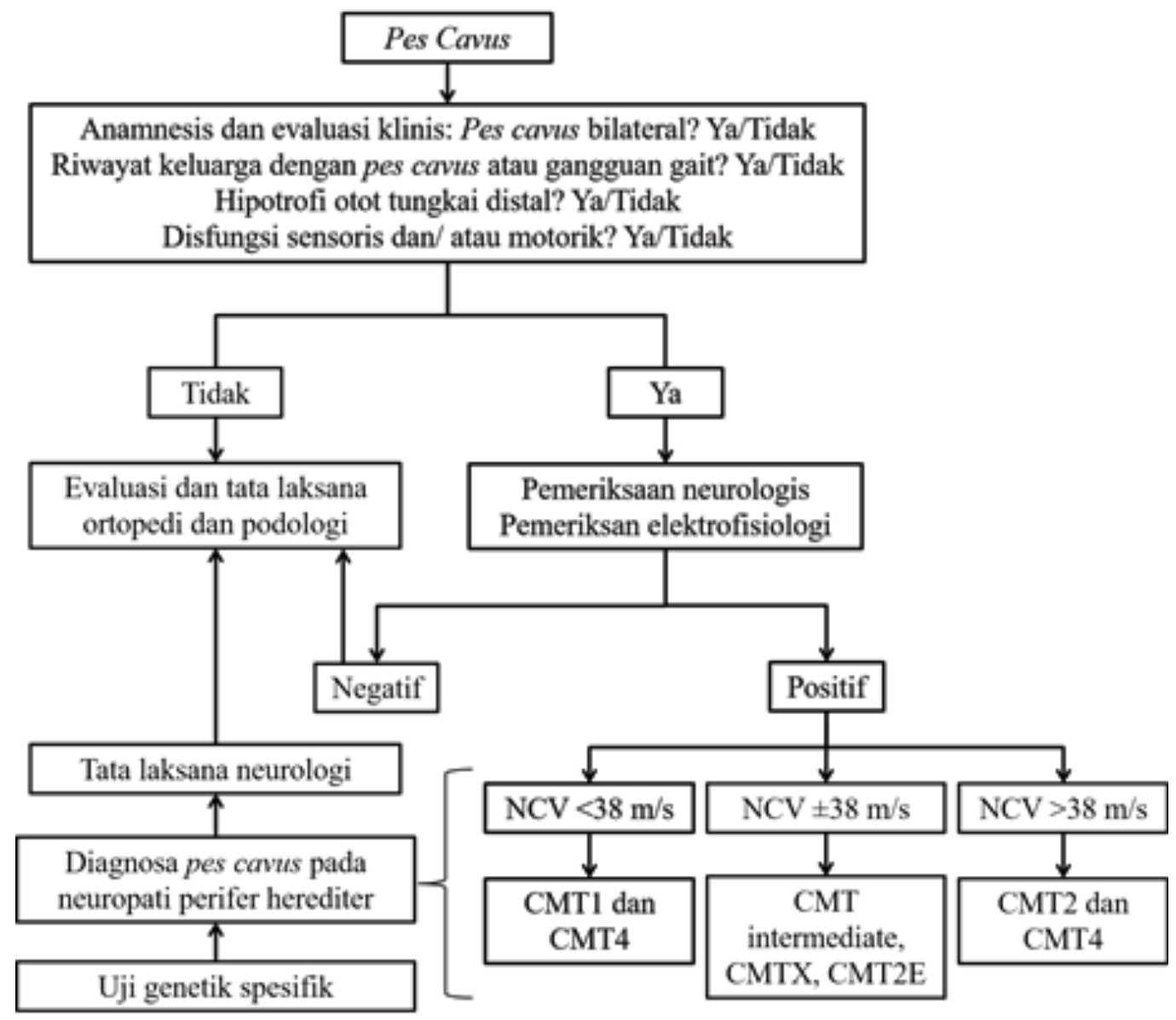

Gambar 2. Algoritma Penegakan Diagnosis Berdasarkan Adanya Pes Cavus ${ }^{10}$

$\mathrm{NCV}$ : nerve conduction velocity (kecepatan hantar saraf)

pemeriksaan genetik khusus pasien polineuropati herediter ini maka dilakukan strategi pendekatan diagnosis. Pada pasien ini, usia saat terkena digolongkan sebagai onset lanjut (dewasa), gejala yang ditemukan berupa gejala klasik CMT, pemeriksaan elektrofisiologi didapatkan penurunan KHS motorik dengan gambaran perlambatan konduksi seragam, dan riwayat sepupu dari pihak ibu dengan keluhan serupa. Berdasarkan strategi diagnostik diatas, kemungkinan pasien mengalami CMT1 dan perlu dilanjutkan ke pemeriksaan genetik. Pilihan pemeriksaan genetik yang akan diperiksa yaitu gen PMP 22 dan MPZ. Namun, pemeriksaan ini masih terbatas sehingga penegakan diagnosis hanya berdasarkan anamnesis, pemeriksaan fisik, dan pemeriksaan elektrofisiologi.

Penatalaksanaan utama pada pasien ini dengan melakukan fisioterapi dan terapi okupasional. Tujuan dari fisioterapi ini yaitu untuk mempertahankan kekuatan dan tonus otot dan mencegah kontraktur. Terapi okupasi bertujuan untuk memberikan bantuan dan melatih agar pasien mampu melakukan aktivitasnya sehari-hari. Nyeri neuropatik sering ditemui pada kebanyakan penderita CMT. Nyeri seringkali berupa nyeri kronik, simetris, dan mengenai kedua tungkai. Pilihan terapi yang dapat diberikan yaitu trisiklik atau serotonin dan norepinephrine reuptake inhibitors, antidepresan, dan antikonvulsan. Pemberian asam askorbat pada pasien CMT diharapkan dapat memperlambat progresifitas penyakit dengan meningkatkan mielinisasi dan mengurangi ekspresi PMP22. Tata laksana spesifik untuk CMT hingga saat ini masih dalam penelitian., ${ }^{2,49}$

Pada kasus dengan gejala atau tanda yang berat, selain tata laksana fisioterapi dan terapi okupasional, penggunaan ortosis atau alat bantu dapat diberikan. Tindakan pembedahan dapat dipertimbangkan untuk memperbaiki bentuk kaki yang inversi, pes cavus, dan hammer toes sehingga membantu perbaikan saat berjalan dan mengurangi terjadinya ulserasi di plantar., 
CMT bukanlah suatu penyakit yang fatal dan kebanyakan penderita CMT memiliki angka harapan hidup normal. Namun, seiring dengan progresivitasnya, penderita CMT dapat mengalami deformitas yang membuat menurunnya kualitas hidup. ${ }^{2}$

\section{KESIMPULAN}

Strategi diagnostik (usia, tanda dan gejala, pemeriksaan elektrofisiologi, pola pewarisan, dan etnis) membantu menegakkan diagnosis sebelum pemeriksaan genetik. Progresivitas CMT memengaruhi kualitas hidup pasien sehingga diperlukan fisioterapi dan terapi okupasional.

\section{DAFTAR PUSTAKA}

1. Daroff RB, Jankovic J, Mazziotta JC, Pomeroy SL. Bradley's neurology in clinical practice. Edisi ke-7. London: Elsevier; 2012. h.1812-8.

2. Louis ED, Mayer SA, Rowland LP. Merritt's neurology. Edisi ke-13. Philadelphia: Wolters Kluwer; 2016. h. 775-84.

3. Morena J, Gupta A, Hoyle JC. Charcot-MarieTooth: from molecules to therapy. Int J Mol Sci. 2019;20(14):3419.

4. Gutmann L, Shy M. Update on Charcot-Marie-Tooth disease. Curr Opin Neurol. 2015;28(5):462-7.

5. Juarez P, Palau F. Neural and molecular features on Charcot-Marie-Tooth disease plasticity and therapy. Neural Plast. 2012;2012:1-11.
6. Barreto LC, Oluiveira FS, Nunes PS, Garcez CA, Goes GM, Neves ELA, dkk. Epidemiologic study of Charcot-Marie-Tooth disease: a systematic review. Neuroepidemiology. 2016;46:157-65.

7. Lindsay KW, Bone I, Fuller G. Neurology and neurosurgery illustrated. Edisi ke-5. Edinburgh: Churchil Livingstone Elsevier; 2010. h.444.

8. Mondal RL, Koneri R, Nagarathna PKM. A detailed study on a rare disease: Charcot Marie Tooth (CMT). J Pharm Biol Sci. 2014;9(2):29-39.

9. McCorquodale D, Pucillo EM, Johnson NE. Management of Charcot-Marie-Tooth disease: improving long-term care with a multidiciplinary approach. J Multidiscip Healthc. 2016;9:7-19.

10. Piazza S, Ricci G, Ienco EC, Carlesi C, Volpi L, Siciliani G, dkk. Pes cavus and hereditary neuropathies: when a relationship should be suspected. J Orthop Traumatol. 2010:11;195-201.

11. Catena F, Doty JF, Jastifer J, Coughlin MJ, Stevens S. Prospective study of hammertoe correction with an intramedullary implant. Foot Ankle Int. 2014;35(4):319-25.

12. Basile A, Albo F, Via AG. Intramedullary fixation system for the treatment of hammertoe deformity. J Foot Ankle Surg. 2015;54:910-6.

13. Kwon OY, Tuttle LJ, Johnson JE, Mueller MJ. Muscle imbalance and reduced ankle joint motion in people with hammer toe deformity. Clin Biomech. 2009;24(8):670-5. 